\title{
Kikkhullskirurgi bør være førstevalg ved leverreseksjon
}

\section{Leverreseksjon med kikkhullskirurgi er pasientvennlig, har lav kom- plikasjonsrate og gir relativt høy overlevelse for kreftpasienter med levermetastaser fra tykktarmskreft.}

Siden 1980-årene er stadig flere pasienter blitt behandlet med leverreseksjon. Dette har gjort det mulig å kurere og forlenge livet til et stort antall pasienter, først og fremst pasienter med metastaser fra tykktarmskreft til leveren.

De senere år er teknikker for minimalt invasiv leverkirurgi blitt utviklet, nemlig kikkhullskirurgi og ablasjon, dvs. termisk behandling. Høyintensitetsfokusert ultralyd (HIFU) er en ny og lovende ablasjonsteknikk. Ved denne metoden blir ultralydenergi konsentrert i et lite område og temperaturen i denne sonen øker, noe som fører til at cellene dør. Metoden trenger eksperimentell evaluering og validering før klinisk bruk.

Den første delen av min avhandling er basert på et materiale med over 200 pasienter som på Oslo universitetssykehus, Rikshospitalet i perioden 1998-2010 ble operert med kikkhullskirurgi for lidelser i leveren. De viktigste funnene var høy overlevelse og lavt tilbakefall av sykdom. Liggetid etter operasjon og komplikasjonsfrekvens var lavere enn det som er forventet ved tradisjonell, åpen kirurgi. De kosmetiske resultatene var også meget gode.

I den siste studien i avhandlingen utforsket vi høyintensitetsfokusert ultralyd utført på en grisemodell. Her avslørte vi noen utfordringer ved anvendelse av energi ved fokusert ultralyd. Disse gjaldt både valg av behandlingsregime (energi, behandlingstid, tilgang) og fortolkning av vevsskade.

Kikkhullskirurgi bør være førstevalgsbehandling ved leverreseksjon ved sentre der man behersker teknikken på et fullgodt nivå. Høyintensitetsfokusert ultralyd er fortsatt bare i eksperimentell bruk her i landet, og de utfordringene vi fant, må løses før metoden kan anvendes på pasienter.

\section{Airazat M. Kazaryan}

kazair@sthf.no

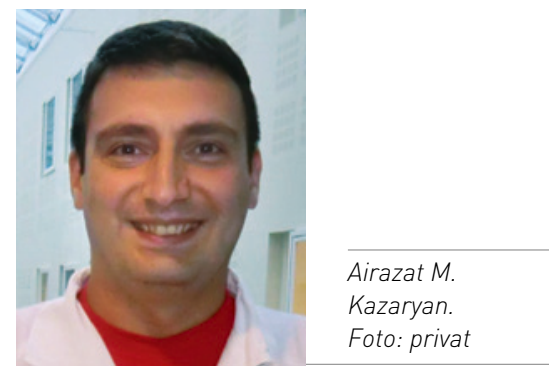

Disputas

Airazat M. Kazaryan disputerte for ph.d.-graden ved Universitetet i Oslo 17.6. 2013. Tittelen på avhandlingen er New minimally invasive techniques in the treatment of patients with lesions in the liver: laparoscopy and extracorporeal high intensity focused ultrasound.

\section{Ulik behandling med vitamin $\mathrm{K}$-antagonister}

\author{
Det er stor variasjon i bruken av warfarin og tilsvarende vitamin K-anta- \\ gonister i Norge og internasjonalt.
}

I Norge behandles ca. 94000 pasienter med vitamin K-antagonisten warfarin for å hindre blodpropp. Kvaliteten på behandlingen kan måles som tid i terapeutisk INR-område, og denne varierer mellom ulike land. I Norge er kvaliteten generelt sett god. Vi ønsket å se om det var samsvar mellom den praktiske håndteringen av slik behandling og publiserte retningslinjer.

I de to første artiklene i min avhandling fikk leger i Norge og 12 andre land (Australia og 11 europeiske land) presentert sykehistorier med spørsmål om hvordan de ville håndtere ulike problemstillinger rundt behandling med vitamin K-antagonister. De ble blant annet spurt om hvor ofte de ville analysere INR-verdier, hvordan de ville dosere medikamentet og hvordan de ville håndtere en høy INR-verdi. Det ble funnet stor variasjon i praksis både hos legene i Norge og i andre land, og også blant leger som brukte standardiserte doseringsskjemaer. Det er fortsatt nød- vendig å arbeide for økt standardisering av behandlingen, utvikling av mer praktiske retningslinjer og økt kjennskap til de retningslinjer som finnes.

Blodpropp i svangerskapet og rett etter fødsel er sjelden, men risikoen for dette er 4-6 ganger så stor sammenliknet med risikoen hos ikke-gravide kvinner. Det kan være vanskelig å stille diagnosen blodpropp hos gravide. I den tredje artikkelen i avhandlingen fulgte vi friske gravide og ikke-gravide kvinner med analysering av D-dimer. Vi foreslo en modell for hvordan man kan beregne om økningen i D-dimer hos en gravid er som forventet $\mathrm{i}$ et normalt svangerskap. Flere studier er nødvendig for å kunne avgjøre om denne metoden er aktuell å bruke i klinisk praksis.

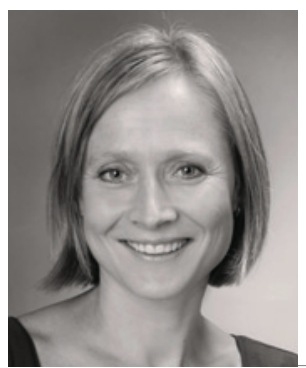

Ann Helen Kristoffersen. Foto: Anne Sidsel Herdlevær

Disputas

Ann Helen Kristoffersen disputerte for ph.d.graden ved Universitetet i Bergen 27.9. 2013. Tittelen på avhandlingen er Aspects of the use and interpretation of INR and D-dimer in primary and secondary care. Discussed in relation to different phases in laboratory medicine.

\section{Ann Helen Kristoffersen}

ann.kristoffersen@helse-bergen.no 